\title{
Bibliometric analysis of cerebral palsy and oral health in PubMed (1956-2021)
}

\author{
Análise bibliométrica sobre paralisia cerebral e saúde oral no PubMed (1956-2021) \\ Análisis bibliométrico de parálisis cerebral y salud bucal en PubMed (1956-2021)
}

\author{
Gabriela Mancia de Gutierrez \\ ORCID: https://orcid.org/0000-0003-1538-5823 \\ Universidade Cruzeiro do Sul, Brasil \\ E-mail: gabrielamancia@hotmail.com \\ Ana Cristina Fernandes Maria Ferreira \\ ORCID: https://orcid.org/0000-0001-5154-7530 \\ Universidade Cruzeiro do Sul, Brasil \\ E-mail: anacristina.ferreira@gmail.com \\ Carlos Felipe Bonacina \\ ORCID: https://orcid.org/0000-0003-4757-0724 \\ Universidade Cruzeiro do Sul, Brasil \\ E-mail: felipebonacina@msn.com \\ Vanessa Lira Siqueira \\ ORCID: https://orcid.org/0000-0001-9521-3110 \\ Universidade Cruzeiro do Sul, Brasil \\ E-mail: vanricsiqueira@gmail.com \\ Maria Teresa Botti Rodrigues Santos \\ ORCID: https://orcid.org/0000-0002-1276-8012 \\ Universidade Cruzeiro do Sul, Brasil \\ E-mail: drsantosmt@yahoo.com.br
}

\begin{abstract}
Cerebral palsy $(\mathrm{CP})$ is the most common motor disability in childhood, and as far as we know, there are no biometric studies that have evaluated $\mathrm{CP}$ and oral health $(\mathrm{OH})$ on a global level. The aim of this study was to present the worldwide research trends in studies of $\mathrm{OH}$ in persons with $\mathrm{CP}$, using bibliometric analysis. Through bibliographic information on publications about $\mathrm{OH}$ and $\mathrm{CP}$ was obtained in the PubMed database, from 1956 to 2021. The extracted data included periodical, title, year of publication, authors, citations, impact factor, key words, country, most cited publications, and study design. A total of 567 articles were published and indexed in PubMed up until 6/28/2021. The data showed a constant growth and an exponential increase in the number of publications. The articles were written in 17 different languages, and 232 (90.63\%) articles were in English. Among the 111 Periodicals, Special Care in Dentistry contributed the most to scientific research with 30 articles (17.3\%). Brazil (25\%) and the United States (17.24\%) were the countries with the highest number of publications. Observational studies were the most frequent types of articles (76.29\%), followed by case reports (13.36\%). It was concluded that this current network analysis indicates that although there is a significant growth in the number of publications about $\mathrm{OH}$ in persons with $\mathrm{CP}$, it is important to increase the number of interventional randomized clinical trial studies, to include this population in high-impact oral health investigations around the world.
\end{abstract}

Keywords: Bibliometrics; PubMed; Cerebral palsy; Oral health; Dental care for disabled.

\section{Resumo}

A paralisia cerebral (PC) é a causa mais comum de deficiência física na infância e até onde sabemos, nenhum estudo bibliométrico avaliou a PC e a saúde bucal (SB) em nível global. O objetivo deste trabalho é apresentar a tendência mundial de pesquisa em estudos sobre SB de pessoas com PC, por meio de análise bibliométrica. Através de informações bibliográficas das publicações sobre SB e PC foram obtidas na base de dados PubMed, de 1956 a 2021. Os dados extraídos foram periódico, título, ano de publicação, autores, citações, fator de impacto, palavras-chave, país, publicações mais citadas e desenho do estudo. Um total de 567 artigos foram publicados e indexados no PubMed até 28/06/2021. Os dados indicaram um crescimento constante e um aumento exponencial no número de publicações. Os artigos foram escritos em 17 idiomas diferentes, dos quais 232 (90,63\%) artigos foram incluídos por estarem em inglês. Entre os 111 periódicos, a Special Care in Dentistry a que teve mais contribuição à pesquisa científica com 34 artigos (17,3\%). O Brasil (25\%) e os Estados Unidos da América $(17,24 \%)$ foram os países com maior produção de publicações. Estudos observacionais foi o tipo de artigo mais frequente (76,29\%), seguido pelos relatos de caso (13,36\%). Concluise que estra análise da rede mundial indica que há um crescimento significativo no número de publicações sobre SB e pessoas com PC, é importante aumentar o número de estudos de ensaio clínico randomizado intervencionista, para incluir esta população em investigações de alto impacto de saúde bucal em todo o mundo. 
Palavras-chave: Bibliometria; PubMed; Paralisia cerebral; Saúde bucal; Assistência odontológica para pessoas com deficiências.

\section{Resumen}

La parálisis cerebral (PC) es la causa más común de discapacidad física en la infancia y, hasta donde sabemos, ningún estudio bibliométrico ha evaluado la PC y la salud bucal (SB) a nivel mundial. El objetivo de este artículo es presentar la tendencia de investigación mundial en estudios sobre SB en personas con PC, a través del análisis bibliométrico. A través de información bibliográfica de publicaciones sobre SB y CP, se obtuvo la base de datos PubMed desde 1956 hasta 2021. Los datos extraídos fueron revista, título, año de publicación, autores, citas, factor de impacto, palabras clave, país, publicaciones más citadas y diseño del estudio. Un total de 567 artículos fueron publicados e indexados en PubMed hasta el 28/06/2021. Los datos indicaron un crecimiento constante y un aumento exponencial en el número de publicaciones. Los artículos se redactaron en 17 idiomas diferentes, de los cuales 232 (90,63\%) se incluyeron por estar en inglés. Entre las 111 revistas, Special Care in Dentistry tuvo la mayor contribución a la investigación científica con 34 artículos (17,3\%). Brasil (25\%) y Estados Unidos de América (17,24\%) fueron los países con mayor producción de publicaciones. Los estudios observacionales fueron el tipo de artículo más frecuente $(76,29 \%)$, seguidos de los casos clínicos $(13,36 \%)$. Se concluye que este análisis de la red mundial indica que existe un crecimiento significativo en el número de publicaciones sobre SB y personas con PC, es importante incrementar el número de estudios de ensayos clínicos intervencionistas aleatorizados para incluir a esta población de alto impacto en investigaciones sobre salud en todo el mundo.

Palabras clave: Bibliometría; PubMed; Parálisis cerebral; Salud bucal; Atención dental para personas con discapacidades.

\section{Introduction}

Dentistry is a vast area within the health sciences, with a large number of subareas, and among them, dental care for the disabled. Among the various types of persons with disabilities, cerebral palsy is the most common cause of physical disability in childhood. Persons with cerebral palsy often present permanent disorders in development, movement and posture, causing limitation in daily activity, and is attributed to nonprogressive disturbances which occur in the developing fetal or infant brain (Rosenbaum et al. 2007).

A bibliographic review evaluated 11 articles about oral health of children with cerebral palsy and Down Syndrome in order to define possible differences between those and the general population. The results demonstrated that children with cerebral palsy present higher prevalence of dental caries and periodontal disease and worse health, compared to control groups (Diéguez-Pérez et al. 2016).

Only one systematic review and meta-analysis was found, including 15 articles, which investigated the health of children with cerebral palsy compared to healthy children. A correlation was observed between cerebral palsy and dental caries in primary dentition, gingival status, Angle’s Class II malocclusion and anterior open bite (Bensi et al. 2020).

In addition to dental caries and periodontal disease, other studies of salivary composition (Santos et al. 2016; Santos et al. 2017), malocclusion (Yogi et al. 2018; Miamoto et al. 2010), temporomandibular disorder (Ortega et al. 2008), dental trauma (Cardoso et al. 2015), and a case report of Oral myiasis treated with ivermectin, (Shinohara et al. 2004) were found in the literature involving children and adolescents with cerebral palsy.

Bibliometric analysis can be applied to track development trends, access the influences of publications and compare academic performance between different countries in a given research area (Yao et al. 2018). Bibliometrics is an important tool for the quantitative analysis of the productivity of scientific research, helping to monitor and analyze the structure and growth of science (Cooper 2015).

The number of articles published in the field of dentistry has steadily increased over the past decade. This growth was mainly in research articles (Jayaratne and Zwahlen 2015). Bibliometric studies have shown that there are differences between dental subjects, study categories, and thematic areas. In the last bibliometric reviews of dentistry journals, some specific areas stand out, such as dental materials (Moraes et al. 2020), oral pathology (Bhalla and Chockattu 2020), and endodontics (Estrela 
et al. 2020) but the area of special patients is not even mentioned. However, in some bibliometric reviews with a specific theme in pediatric dentistry, there was a very low percentage of articles published with a specific theme of patients with special needs (6.5\%) (Adobes Martin et al. 2021).

It can be observed that the amount of publications on cerebral palsy has increased in the last 3 years in the medical field. There has been a very large increase in studies on Cerebral Palsy AND Comorbidities, comparing two different periods of time (Klawonn et al. 2020). However, until now no bibliometric study has assessed cerebral palsy and oral health globally.

Bibliometric methods have been used in several fields of dentistry (Patil et al. 2020; Ahmad et al. 2020; Liu et al. 2020) and specific dentistry journals (Valderrama et al. 2020; Bhalla and Chockattu, 2020). The aim of this study was to assess bibliometric characteristics and the worldwide tendency of all articles on cerebral palsy and oral health.

\section{Methodology}

Search Strategy

Bibliometric data can be acquired through various search platforms. In this study, the PubMed database was chosen because of its broad coverage, international visibility, and the controlled vocabulary thesaurus for indexing and retrieving documents (Liu et al. 2020).

To further limit bias, a systematic literature search using a single database (PubMed) and focus on key areas of oral health in the field of cerebral palsy was performed.

A bibliographic search was performed in the PubMed database on June 28, 2021. The keywords used were "cerebral palsy", "oral health", "dental caries", "periodontal disease", "malocclusion", "tooth injuries", "mouth neoplasm", "oral medicine", and "oral manifestations". The search query was built as follows: (("cerebral palsy"[MeSH Terms] OR ("cerebral"[All Fields] AND "palsy"[All Fields])) OR "cerebral palsy"[All Fields]) AND (((c((((("oral health"[MeSH Terms] OR ("oral"[All Fields] AND "health"[All Fields])) OR "oral health"[All Fields]) OR (("dental caries"[MeSH Terms] OR ("dental"[All Fields] AND "caries"[All Fields])) OR "dental caries"[All Fields])) OR (("periodontal diseases"[MeSH Terms] OR ("periodontal"[All Fields] AND "diseases"[All Fields])) OR "periodontal diseases"[All Fields])) OR (((("malocclusal"[All Fields] OR "malocclusion"[MeSH Terms]) OR "malocclusion"[All Fields]) OR "malocclusions"[All Fields]) OR "malocclusive"[All Fields])) OR (("tooth injuries"[MeSH Terms] OR ("tooth"[All Fields] AND "injuries"[All Fields])) OR "tooth injuries"[All Fields])) OR (("mouth neoplasms"[MeSH Terms] OR ("mouth"[All Fields] AND "neoplasms"[All Fields])) OR "mouth neoplasms"[All Fields])) OR (("oral medicine"[MeSH Terms] OR ("oral"[All Fields] AND "medicine"[All Fields])) OR "oral medicine"[All Fields])) OR (("oral manifestations"[MeSH Terms] OR ("oral"[All Fields] AND "manifestations"[All Fields])) OR "oral manifestations"[All Fields])).

Two independent authors evaluated the title and abstract of all articles selected. The following data was extracted: journal, title, year of publication, authors, citations, impact factor, keywords, country, most cited publications and study design. When an abstract failed to provide the necessary information, the full texts were analyzed. Any disagreement about the studies was solved by consensus after a third review author was consulted. The inclusion criteria for article selection were articles in English and fully accessible text. Letters to the editor, duplicated articles, and articles without complete accessibility were excluded. The search strategy is shown in Figure 1. 
Figure 1. Flow diagram for the selection of articles.

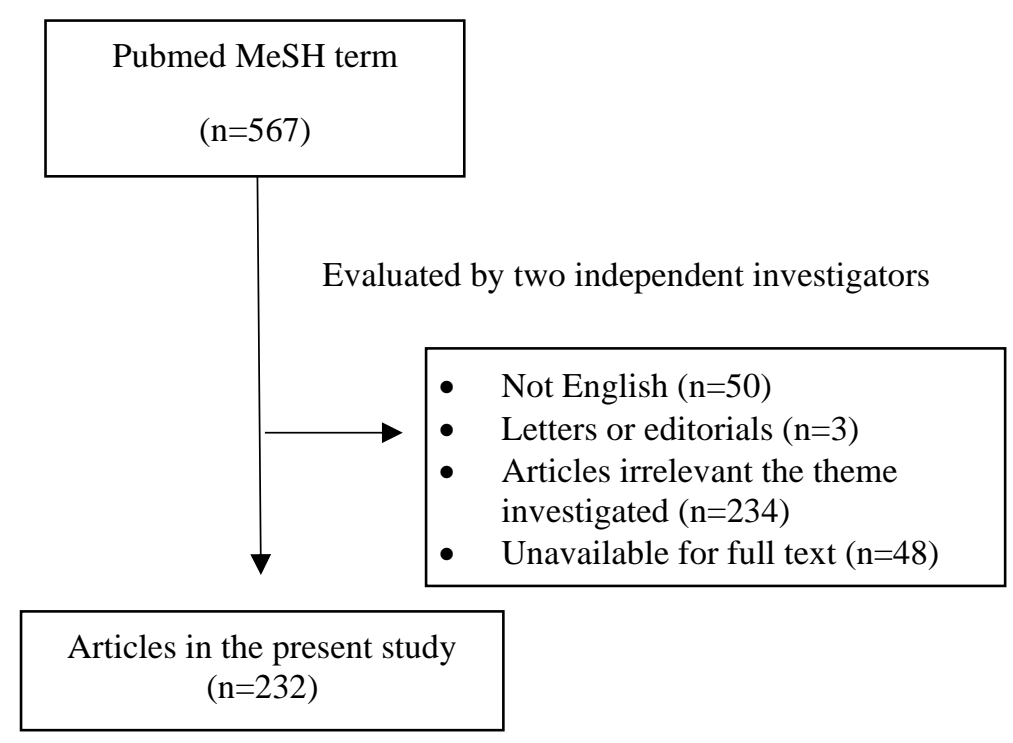

Source: Authors.

Data extraction was divided into two parts, the manual handling was transported to Microsoft Excel to perform statistical procedures. The main journals, countries, authors, institutions and most cited articles were classified according to the standard classification of the competition (SCR). Data visualization was performed using the VOSviewer technique to create scientific landscapes and networks based on citation frequency, countries, journals, authors and other information (van Eck and Waltman 2010). GunnMap 2 (http://lert.co.nz/map/) was used to generate the world map to show the publication distribution.

Study designs were classified as follows: observational, case report, literature review, systematic review (with metaanalysis or not), in vitro and interventional study.

\section{Results}

After applying the keywords cerebral palsy, oral health, dental caries, periodontal disease, malocclusion, tooth injuries, mouth neoplasm, oral medicine, and oral manifestations, the first article to be retrieved was from the year 1956 (Lyons 1956). Thus, there was no year restriction regarding the inclusion of studies (1956 - 2021). The applied strategy yielded a total of 567 articles.

After the preliminary screening, 335 publications were excluded. Among the total 567 documents there were multiple source types written in 17 different languages. Two hundred and thirty-two English language papers were included for the subsequent analyses, after applying the exclusion criteria: non-English articles, irrelevant articles on cerebral palsy and oral health, letters to editors, editorials, and articles that were unavailable in full-text were excluded.

\section{Articles published per year}

From 1956-2021, a total of 232 articles about cerebral palsy and oral health were published and indexed in PubMed, with an average of 5.54 per year. The specific numbers of annual documents are shown in Figure 2. The highest number of annual publications occurred in 2018, totaling 17 publications. 
Figure 2. Number of articles published per year.

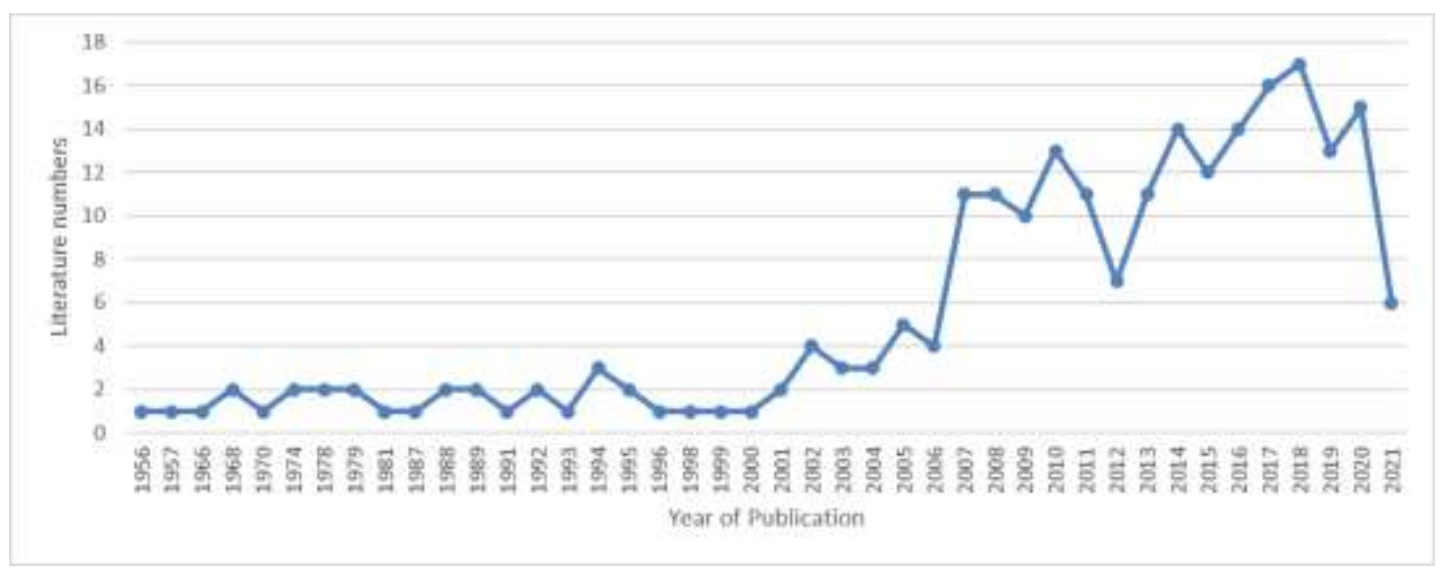

Source: Research data.

\section{Country and Publication}

The geographical distribution of publications included 35 countries/regions over six continents, as displayed in the density world map in Figure 3. There were 16 countries that published only one article each, and 10 countries that published at least five articles each. The top 10 most productive countries are shown in figure 3A. Brazil was the most productive country (25\%, 58/232), followed by the US (40 publications), India (22 publications), Spain (13 publications), and Turkey (12 publications). Among these countries, five were developed countries (according to the definition of the United Nations www.un.org) while five were developing countries.

Figure 3. Countries and regions that have contributed with articles about cerebral palsy and oral health worldwide. (A) Top 10 countries that have contributed to publications about cerebral palsy and oral health. (B) The density world map. The different colors represent the number of published articles.

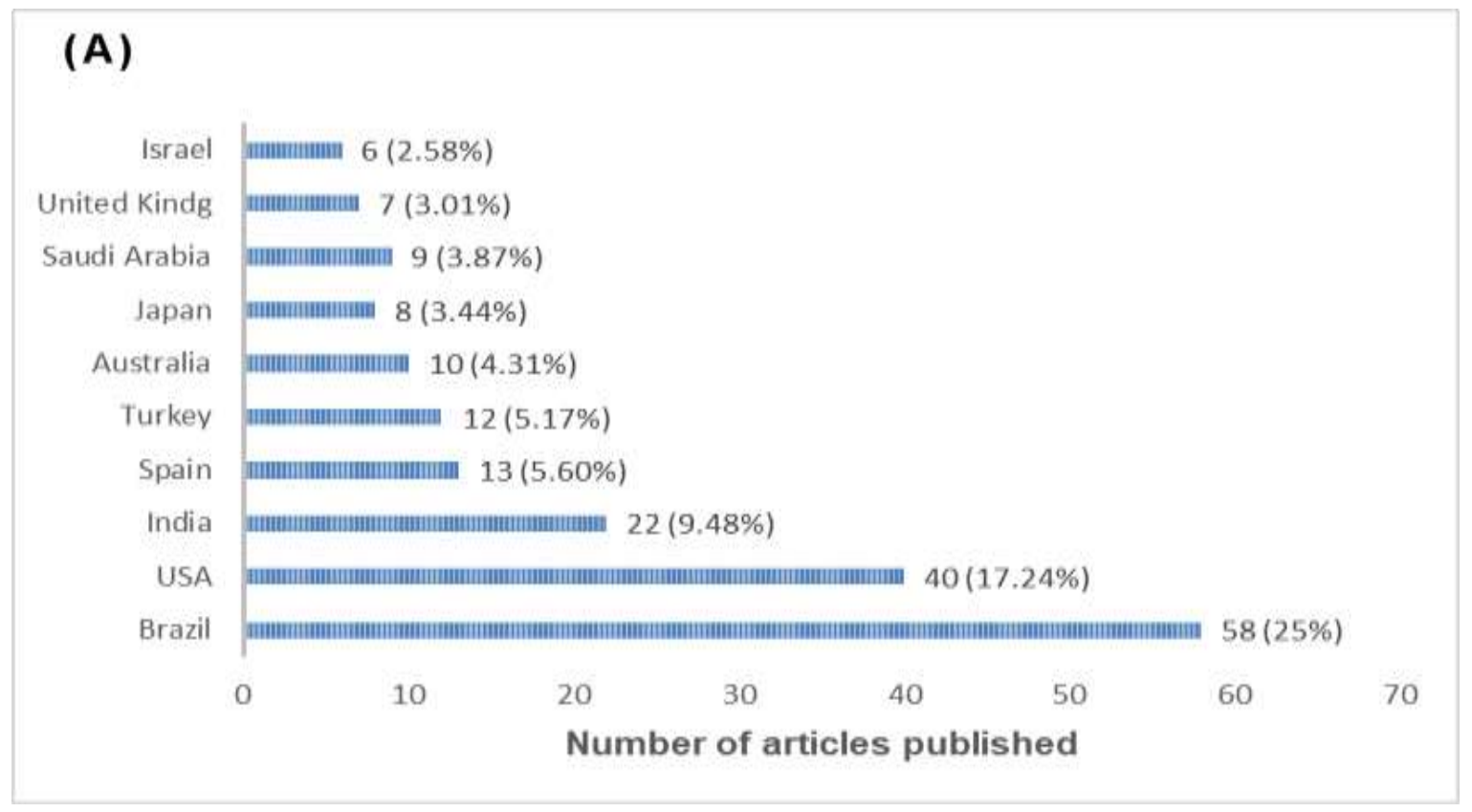




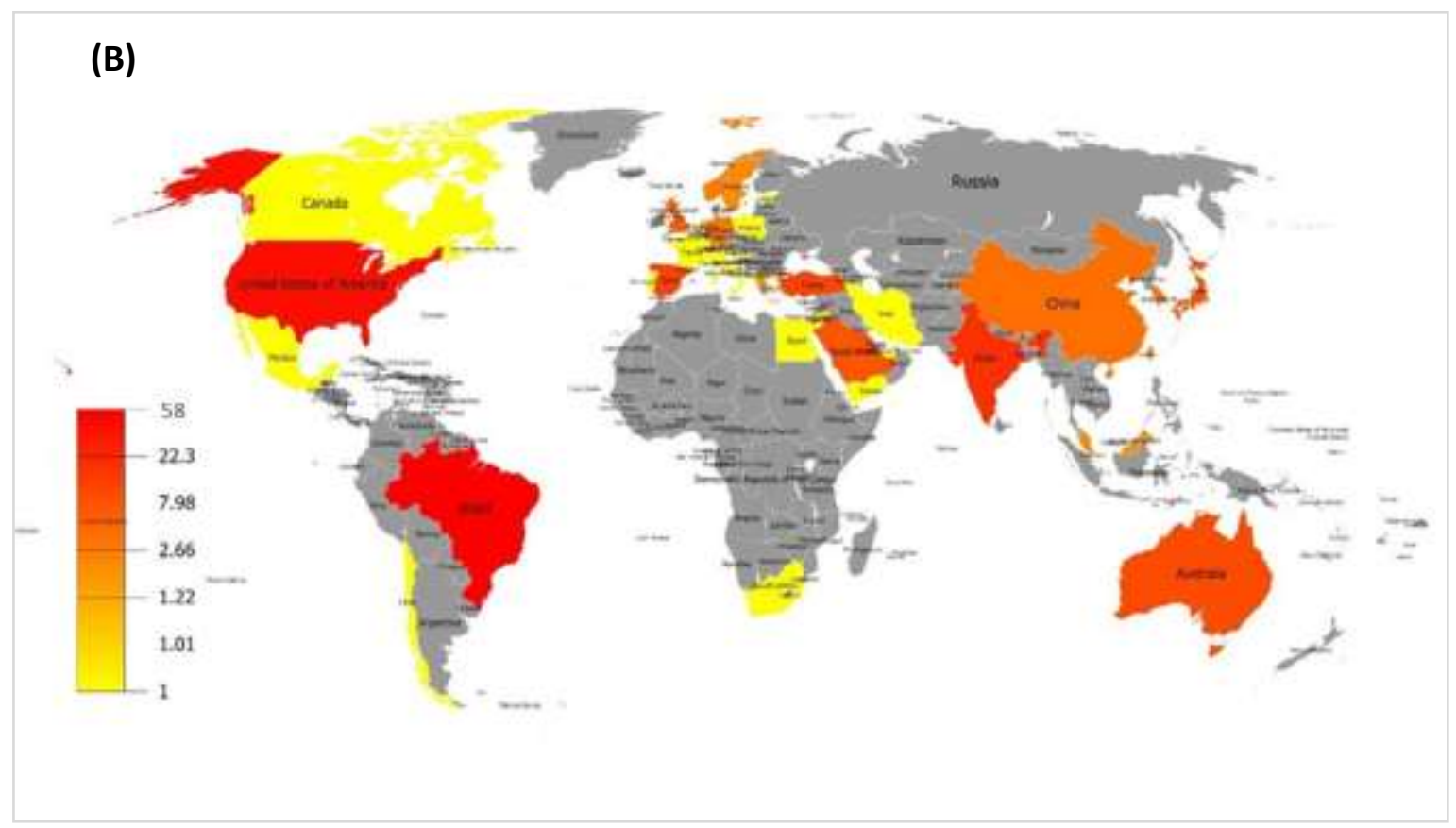

Source: Research data.

\section{Authors contribution}

A total of 796 authors contributed to the publication of all the 232 papers included. The number of authors for a single document, also known as the transience index, is 149 , accounting for $18.7 \%$ of all the authors. Only two authors published more than nine articles in this field. Santos, MTBR was the most productive author in this field with 22 publications, followed by de Oliveira Guaré, R (10 publications) both from Brazil. The top five productive authors in the field of cerebral palsy and oral health are shown in Table 1. There are thirteen authors in the top five lists because eleven authors published an equal number of articles.

Table 1. Top 5 productive authors in the field of cerebral palsy and oral health affiliation.

\begin{tabular}{lcl}
\hline Author & $\begin{array}{c}\text { Number of } \\
\text { publications }\end{array}$ & Affiliation \\
\hline Santos MTBR & 22 & Cruzeiro do Sul University \\
de Oliveira Guaré R & 10 & Cruzeiro do Sul University \\
Ferreira ACFM & 6 & Cruzeiro do Sul University \\
Ramos-Jorge ML & 6 & Federal University of Vales do Jequitinhonha e Mucuri \\
Ciamponi AL & 5 & University of São Paulo \\
Diniz MB & 5 & Cruzeiro do Sul University \\
Ferreira MCD & 5 & Methodist University of São Paulo \\
Demir N & 4 & Hacettepe University \\
Karaduman AA & 4 & Hacettepe University \\
Marques LS & 4 & Vale do Rio Verde University \\
Mendes FM & 4 & University of São Paulo \\
Nigel M King & 4 & The University of Hong Kong \\
Serel Arslan S & 4 & Hacettepe University \\
\hline
\end{tabular}

Source: Research data.

A total of 660 authors have been cited at least once, accounting for $82.9 \%$ of the total 796 authors. Twenty-five authors had at least four citation numbers (3.14\%), and 6 authors have been cited at least four times $(0.75 \%)$. Santos, MTBR was the 
most influential author with the greatest citation number of 906, followed by de Oliveira Guaré R (340) and Ramos-Jorge ML (255); details of citation analysis are represented in Figure 4.

Among the top 10 most cited authors, Santos, MTBR had the greatest citation numbers per publication (43.14), followed by de Oliveira Guaré R and Ramos-Jorge ML all from Brazil.

Figure 4. Citation analysis of 38 authors with at least three publications. The lines indicate collaborations. Authors represented with larger circle size or font size had relatively more citations. Colors represent year of publication.

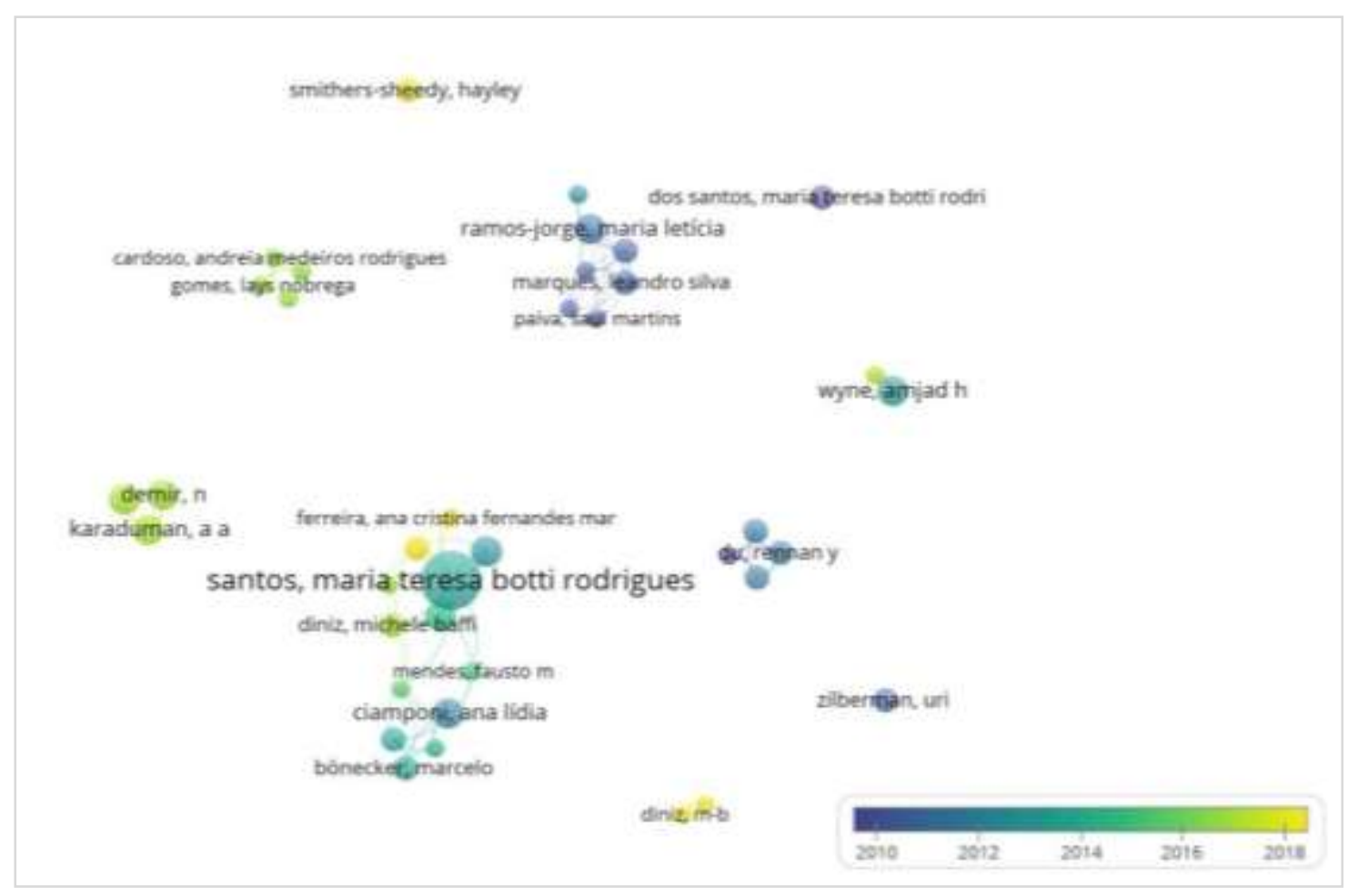

Source: Research data.

\section{Institutions Involved}

Institutions that are prolific in publishing papers on oral health and cerebral palsy are presented in Table 2. The most active institutions were Cruzeiro do Sul University in Brazil (21 publications), followed by University of São Paulo-USP in Brazil (8 publications), and Tufts University School of Dental Medicine in the US (4 publications). Among the top 10 most active institutions, four are in Brazil, and two in Australia. A total of 153 organizations have been cited. 
Table 2. Top 10 prolific institutions and countries in publishing papers about cerebral palsy and oral health.

\begin{tabular}{lcccc}
\hline SCR & Institution & Country & Documents & \% N = 232 \\
\hline 1st & Cruzeiro do Sul University & Brazil & 21 & 9.05 \\
2nd & University of São Paulo-USP & Brazil & 8 & 3.44 \\
3rd & Tufts University School of Dental Medicine & US & 4 & 1.72 \\
4th & King Saud University College of Dentistry & Saudi Arabia & 4 & 1.72 \\
5th & University of Seville & Spain & 3 & 1.29 \\
6th & The University of Hong Kong & China & 3 & 1.29 \\
7th & Vale do Rio Verde University & Brazil & 3 & 1.29 \\
8th & Federal University of Minas Gerais State & Brazil & 3 & 1.29 \\
9th & University of Melbourne & Australia & 3 & 1.29 \\
10th & The University of Sydney & Australia & 3 & 1.29 \\
\hline
\end{tabular}

Legends: SCR, standard competition ranking. Source: Research data.

\section{Keywords}

There were 703 keywords in the 232 articles. The visualization of keywords is shown in Figure 5. This analysis was performed based on the terms extracted from the title and abstract fields of retrieved publications; a number of 35 terms met the threshold with a minimum number of 3 occurrences. The term with the highest frequency was cerebral palsy (107), followed by oral health (32), and dental caries (21).

Figure 5. Word frequency analysis. The density visualization map of the top 35. The larger circle size or font size indicates higher occurrence.

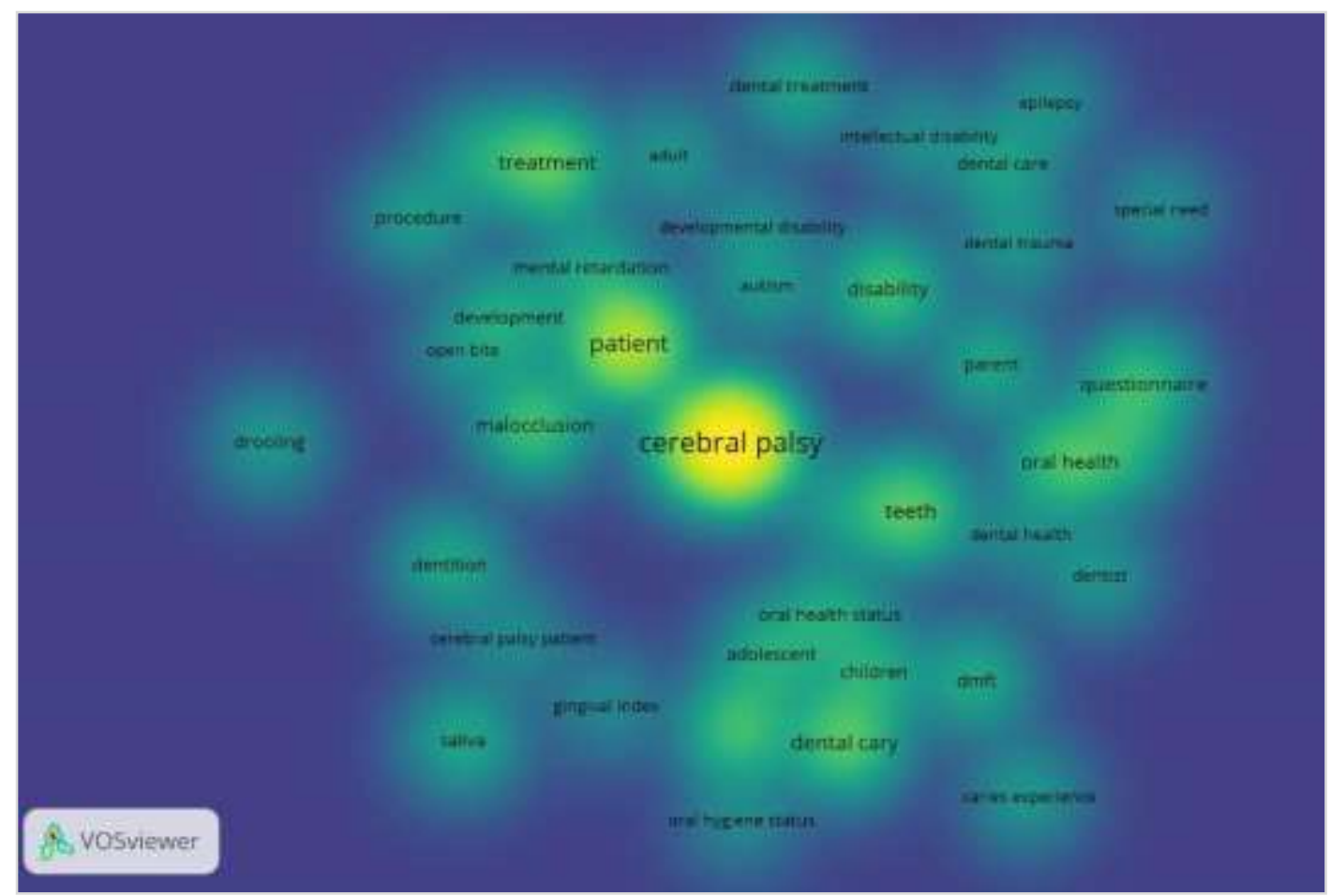

Source: Research data. 


\section{Study design}

Of the 232 articles, the majority $(177,76.29 \%)$ were observational studies. Among observational studies, cross-sectional studies were the most frequent type of article $(78,44.06 \%)$, followed by case reports $(31,13.36 \%)$, reviews $(12,5.17 \%)$, interventional studies $(7,3.01 \%)$, systematic reviews $(5,2.15 \%)$ and only one study in vitro $(0.43 \%)$.

All documents collected were published in 111 different periodicals. Table 3 shows the most productive journals. The top 5 journals published $46.12 \%$ (107/232) of the articles. Eleven journals were published in developed countries, while two were published in a developing country. The most productive journals in this field were Special Care in Dentistry, Dental Traumatology, and Journal of Clinical Pediatric Dentistry.

Table 3. Top 5 periodicals with publications on cerebral palsy and oral health.

\begin{tabular}{|c|c|c|c|c|}
\hline SCR & Journals & Documents & $\% \mathrm{~N}=232$ & IF \\
\hline 1 st & Special Care in Dentistry & 40 & 17.3 & 0.64 \\
\hline 2nd & Dental Traumatology & 8 & 3.5 & 1.53 \\
\hline 2nd & Journal of Clinical Pediatric Dentistry & 8 & 3.5 & 0.94 \\
\hline 2nd & Medicina Oral Patologia Oral y Cirurgia Bucal & 8 & 3.5 & 1.475 \\
\hline $3 \mathrm{rd}$ & Journal of Oral Rehabilitation & 7 & 3.0 & 2.341 \\
\hline $3 \mathrm{rd}$ & International Journal of Paediatric Dentistry & 8 & 3.5 & 1.933 \\
\hline 4th & Developmental Medicine \& Child Neurology & 5 & 2.2 & 4.406 \\
\hline 5 th & $\begin{array}{l}\text { Journal of Indian Society of Pedodontics and Preventive } \\
\text { Dentistry }\end{array}$ & 4 & 1.7 & NA \\
\hline 5 th & $\begin{array}{l}\text { American Journal of Orthodontics and Dentofacial } \\
\text { Orthopedics }\end{array}$ & 4 & 1.7 & 1.960 \\
\hline 5 th & BMC Oral Health & 4 & 1.7 & 1.911 \\
\hline 5 th & Brazilian Oral Research & 4 & 1.7 & 1.223 \\
\hline 5 th & The Journal of the American Dental Association & 4 & 1.7 & 2.803 \\
\hline 5th & Research in Developmental Disabilities & 4 & 1.7 & 1.836 \\
\hline
\end{tabular}

Legends: SCR, standard competition ranking; IF, impact factor; NA, not available. Source: Research data.

The top 10 cited articles are shown in Table 4 (Autun et al. 2010, Rodrigues dos Santos et al. 2003, Loo et al. 2008, Shinohara et al. 2004, Nelson et al. 2011, Mitsea et al. 2001, Benfer et al. 2013, Loo et al. 2009, dos Santos et al. 2005, Francis et al. 1987). The highest citation number was 233 for the article entitled "Oral health status of disabled individuals attending special schools - 2010" (Autun et al. 2010). All 10 most cited articles were published in different periodicals. Regarding the authors, Santos MTBR and Loo CY published two articles among the 10 most cited articles. 
Table 4. Top 10 cited articles on cerebral palsy and oral health.

\begin{tabular}{|c|c|c|c|c|c|}
\hline SCR & Article & Title & Year & Journal & $\begin{array}{c}\text { Cited } \\
\text { by }\end{array}$ \\
\hline 1 st & $\begin{array}{l}\text { Autun et al. } \\
\text { (2010) }\end{array}$ & $\begin{array}{l}\text { Oral health status of disabled individuals attending } \\
\text { special schools - } 2010 \text { - Eur J Dent }\end{array}$ & 2010 & Eur J Dent & 233 \\
\hline 2nd & $\begin{array}{l}\text { Santos et al. } \\
\quad(2003)\end{array}$ & Oral conditions in children with cerebral palsy & 2003 & $\begin{array}{c}\text { J Dent } \\
\text { Child(child) }\end{array}$ & 205 \\
\hline $3 \mathrm{rd}$ & $\begin{array}{l}\text { Loo et al. } \\
\text { (2008) }\end{array}$ & $\begin{array}{l}\text { The caries experience and behavior of dental patients } \\
\text { with autism spectrum disorder }\end{array}$ & 2008 & $\begin{array}{l}\text { J Am Dent } \\
\text { Assoc }\end{array}$ & 209 \\
\hline 4th & $\begin{array}{l}\text { Shinohara et al. } \\
\text { (2004) }\end{array}$ & Oral myiasis treated with ivermectin: case report & 2004 & $\begin{array}{c}\text { Brazilian } \\
\text { Dental Journal }\end{array}$ & 196 \\
\hline 5th & $\begin{array}{l}\text { Nelson et al. } \\
\text { (2011) }\end{array}$ & $\begin{array}{l}\text { Unmet dental needs and barriers to care for children } \\
\text { with significant special health care needs }\end{array}$ & 2011 & Pediatr Dent & 192 \\
\hline 6th & $\begin{array}{l}\text { Mitsea et al. } \\
\quad(2002)\end{array}$ & $\begin{array}{l}\text { Oral health status in Greek children and teenagers, with } \\
\text { disabilities }\end{array}$ & 2002 & $\begin{array}{l}\text { J Clin Pediatr } \\
\text { Den }\end{array}$ & 161 \\
\hline 7th & $\begin{array}{l}\text { Benfer et al. } \\
\quad(2013)\end{array}$ & $\begin{array}{c}\text { Oropharyngeal dysphagia and gross motor skills in } \\
\text { children with cerebral palsy }\end{array}$ & 2013 & Pediatrics & 156 \\
\hline 8th & $\begin{array}{l}\text { Loo et al. } \\
\text { (2009) }\end{array}$ & $\begin{array}{l}\text { Behaviour guidance in dental treatment of patients with } \\
\text { autism spectrum disorder }\end{array}$ & 2009 & $\begin{array}{l}\text { Int J Paediatr } \\
\text { Dent }\end{array}$ & 148 \\
\hline 9th & $\begin{array}{l}\text { Santos et al. } \\
\quad(2005)\end{array}$ & $\begin{array}{l}\text { Infantile reflexes and their effects on dental caries and } \\
\text { oral hygiene in cerebral palsy individuals }\end{array}$ & 2005 & J Oral Rehabil & 136 \\
\hline 10th & $\begin{array}{l}\text { Francis et al. } \\
\quad(1987)\end{array}$ & $\begin{array}{l}\text { A comparison of three delivery methods of } \\
\text { chlorhexidine in handicapped children. I. Effects on } \\
\text { plaque, gingivitis, and toothstaining }\end{array}$ & 1987 & J Periodontol & 127 \\
\hline
\end{tabular}

Legends: SCR, standard competition ranking. Source: Research data.

\section{Discussion}

As far as we can tell, this is the first bibliometric study that analyzed the distribution of worldwide research on cerebral palsy and oral health through the database available, published and indexed in PubMed (https://pubmed.ncbi.nlm.nih.gov). It is important to emphasize that there was no restriction of periodicals in the surveys carried out in this study. Our assessment of cerebral palsy and oral health publishing trends covered a 65-year period (1956-2021).

Bhalla and Chockattu (2020) performed a bibliometric analysis of the manuscripts published in Journal of Clinical and Experimental Dentistry (J Clin Exp Dent; JCED), from 2009-2019, and received a minor contribution from the fields of Esthetic Dentistry (3.2\%), Odontostomatology for the disabled/special patients (1.3\%), as well as Oral Medicine and Radiology $(0.5 \%)$.

In order to identify "What is the trend in pediatric dentistry?" Adobes Martin et al. (2020) selected and analyzed 200 articles with the highest Altmetric Attention Score (AAS), of which 13 (6.5\%) were about patients with special care needs. Garcovich and Adobes Martin (2019) performed a bibliometric study in the four journals related to Pediatric Dentistry listed in the JCR from 2014 to 2017. The highest AAS were found in those referring to preventive protocols or procedures, OHRQOL (quality of life related to oral health), and patients with special care needs. In some dental journals, there is a specific section for the diagnosis and treatment of dental problems related to patients with disabilities or special needs (Bhalla and Chockattu 2020).

There was a marked growth in the number of publications over the 65 years of evaluation of articles on cerebral palsy and oral health. In 2018, there was a greater number of productions (17 articles) (Figure 2), one being a Randomized Controlled Clinical Trial entitled "Evaluation of the effectiveness of a custom-made toothbrush in maintaining oral hygiene and gingival health in patients with cerebral palsy," published in Special Care in Dentistry from a total of 7 studies with this study design.

There are thirteen journals among the top five categories for most publications, including Developmental Medicine \& Child Neurology and Research in Developmental Disabilities. These two medical and multidisciplinary journals focused on the 
topic of pediatric neurology and neurodisability in early childhood; and problems associated with developmental disabilities, respectively (Table 3). The only dental journal focused on the area of special patients is the Special Care in Dentistry.

Currently, cerebral palsy has been considered more than a motor disorder, and must be understood holistically. It should be seen as a developmental condition, with a high probability of affecting the children's (and family's) trajectory and development, therefore, it is necessary to think about interventions in the context of support and services that promote the development and well-being of the family. It must be considered a long-term condition, and that must be seen as a life perspective (Rosenbaum et al. 2019).

Despite the physical disability and comorbidities present in children and adolescents with cerebral palsy, many clinical studies have been carried out in this population (Rodrigues dos Santos et al. 2003, Santos et al. 2016, Santos et al. 2017, Yoshida et al.2019, Ferreira et al. 2019, Ferreira et al., 2021). The design of a study is an important factor that links research to clinical practice. Regarding the results found in this study, the observational cross-sectional study was the most frequent among all types of studies ( $\mathrm{n}=78,44.06 \%$ ), similar to the results found by Adobes Martin et al. (2021) who assessed trends in pediatric dentistry in an altmetric study ( $\mathrm{n}=53,26.5 \%)$. It is important to emphasize that cross-sectional studies are the best way to determine the prevalence of a condition and are useful in identifying associations (Mann 2003) that can be studied more rigorously through a cohort study or randomized clinical trial.

Since this is the first study that evaluated Bibliographic information of publications about oral health and cerebral palsy, no other study was found to compare to the 31 Case-report found in this study. Liu et al (2020) evaluated traumatic dental injuries in a bibliometric analysis over two decades (1999-2018), and found that most articles were case reports. However, it should be noted that the conclusions of case-reports could not be applied directly in clinical practice (Hurd 2014). Although a low number of interventional studies were observed (3.01\%), an increased number of publications on the theme of this study was observed every decade (Abd-Elmonem et al. 2021, Rai et al. 2018, M Baeder et al. 2017, Inal et al. 2017, Serel et al. 2017, Yitzhak et al. 2017, Feng et al. 2007).

Brazil is the second country with the most dental articles published annually since 2006, according to the Scimago Journal \& Country Rank, 2020, which is powered by the Scopus database (14.12 citations per document, H index 137), preceded by United State (20.25 citations per document, $\mathrm{H}$ index 226).

In the list of the 100 most cited articles in the Journal of Dental Research (JDR), the majority of articles are from the US (52\%) and the 7th country that most contributed was Brazil (Ahmad et al. 2020). In the Brazilian Dental Journal (BDJ), in 30 years of publication, $90 \%$ of the articles originated in Brazil (Moraes et al. 2020). After ten years of scientific production published in Acta Stomatologica Croatica, regarding the affiliation of the corresponding author, there was a higher frequency of publications of foreign origin (53.0\%), Brazil had a greater contribution in these publications (25.9\%) (de Araújo et al. 2020). In the journal Medicina Oral Patología Oral y Cirugía Bucal (2008-2018) authors from 70 countries published 1,518 documents; Spain represents 48.68\%, followed by Brazil (15.55\%) and Turkey (7.38\%) (Valderrama et al., 2020). It is possible to notice that Brazil stands out in the publications of dentistry nationally and internationally. This study, shows that almost $1 / 4$ of the publications on cerebral palsy and oral health originated in Brazil.

The four authors that most published on cerebral palsy and oral health were Brazilian women, Santos, MTBR with the greatest number of publications, followed by de Oliveira Guaré R, Ferreira ACFM and Ramos-Jorge ML. Santos, MTBR who published 2.1 times more than Oliveira Guaré R and 3.5 times more than Ferreira ACFM and Ramos-Jorge ML. Santos, MTBR, Oliveira Guaré R and Ferreira ACFM, whereas three main affiliations were all from Cruzeiro do Sul University in the state of São Paulo, Brazil. 
The main limitation of our study was to include only articles in English and only one database for resources (PubMed). PubMed citations, however, come from MEDLINE indexed journals, journals/manuscripts deposited in PMC, and NCBI Bookshelf https://www.nlm.nih.gov/bsd/difference.html.

The results of this first study that addressed this issue demonstrated that there is a lack of high quality and well-designed clinical studies such as cohort studies and randomized controlled trial contributing to the future of cerebral palsy and health research.

A bibliometric characteristic of all articles published in the Brazilian Dental Journal (BDJ) in its 30 years of existence (1990-2019), is that the 3 authors with the most publications in the BDJ were Brazilians connected to University of São Paulo (USP, 34.5\%), University of Campinas (UNICAMP, 14.7\%), and Paulista State University (UNESP, 14.2\%) (Moraes et al. 2020).

\section{Conclusion}

This current network analysis indicates that while there is expressive growth in the number of publications about health in persons with cerebral palsy, in regards to caries and disease-specific research, there is a lack of mechanistic and comprehensive trial research. Therefore, because there is a lack of interventional studies, including cohort studies and randomized controlled trials, it is necessary to include the cerebral palsy population in high impact oral health investigations globally.

\section{References}

Abd-Elmonem, A. M., Saad-Eldien, S. S., \& El-Nabie, W. A. (2021). Effect of oral sensorimotor stimulation on oropharyngeal dysphagia in children with spastic cerebral palsy: a randomized controlled trial. Eur J Phys Rehabil Med. 10.23736/S1973-9087.21.06802-7.

Adobes Martin, M., Zhou Wu, A., Marques Martínez, L., Gonzalvez Moreno, A. M., Aiuto, R., \& Garcovich, D. (2021). What is trending in paediatric dentistry? An Altmetric study on paediatric dentistry journals. Eur Arch Paediatr Dent. 22(2), 291-299. 10.1007/s40368-020-00564-4.

Ahmad, P., Arshad, A. I., Della Bella, E., Khurshid, Z., \& Stoddart, M. (2020). Systemic Manifestations of the Periodontal Disease: A Bibliometric Review. Molecules. 25(19), 4508. 10.3390/molecules25194508.

Altun, C., Guven, G., Akgun, O. M., Akkurt, M. D., Basak, F., \& Akbulut, E. (2010). Oral health status of disabled individuals attending special schools. Eur J Dent. 4(4), 361-6.

Baeder, F. M., Silva, D. F., de Albuquerque, A. C. L., \& Santos, M. T. B. R. (2017). Conscious Sedation with Nitrous Oxide to control Stress during Dental Treatment in Patients with Cerebral Palsy: An Experimental Clinical Trial. Int J Clin Pediatr Dent. 10(4), 384-390. 10.5005/jp-journals-10005-1470

Benfer, K. A., Weir, K. A., Bell, K. L., Ware, R. S., Davies, P. S., \& Boyd, R. N. (2013). Oropharyngeal dysphagia and gross motor skills in children with cerebral palsy. Pediatrics. 131(5), e1553-62. 10.1542/peds.2012-3093.

Bensi, C., Costacurta, M., D\& ocimo, R. (2020). Oral health in children with cerebral palsy: A systematic review and meta-analysis. Spec Care Dentist. 40(5), 401-411. 10.1111/scd.12506.

Bhalla, V. K., \& Chockattu, S. J. (2020). Publication trends in journal of clinical and experimental dentistry. J Clin Exp Dent. 12(9), e857-e863. $10.4317 /$ jced.56640.

Cardoso, A. M., Silva, C. R., Gomes, L. N., Gomes, M. N, Padilha, W. W., \& Cavalcanti, A. L. (2015). Dental trauma in Brazilian children and adolescents with cerebral palsy. Dent Traumatol. 31(6), 471-6. 10.1111/edt.12184.

Cooper, I. D. (2015). Bibliometrics basics. J Med Libr Assoc. 103(4), 217-8. 10.3163/1536-5050.103.4.013.

De Araújo, R. S., Fernandes Porto, N. V., Laureano, I. C. C., Farias, L., Cavalcanti, A. F. C., Goncharuk-Khomyn, M., \& Cavalcanti, A. L. (2020). Bibliometric Analysis of Acta Stomatologica Croatica: 2009-2018. Acta Stomatol Croat. 54(2), 186-193. 10.15644/asc54/2/9.

Diéguez-Pérez, M., de Nova-García, M. J., Mourelle-Martínez, M. R., \& Bartolomé-Villar, B. (2016). Oral health in children with physical (Cerebral Palsy) and intellectual (Down Syndrome) disabilities: Systematic review I. J Clin Exp Dent. 8(3), e337-43. 10.4317/jced.52922.

Dos Santos, M. T., \& Nogueira, M. L. (2005). Infantile reflexes and their effects on dental caries and oral hygiene in cerebral palsy individuals. J Oral Rehabil. 32(12), 880-5. 10.1111/j.1365-2842.2005.01518.x.

Estrela, C., Pécora, J. D., \& Sousa-Neto, M. D. (2020). The Contribution of the Brazilian Dental Journal to the Brazilian Scientific Research over 30 Years. Braz Dent J. 31(1), 3-9. 10.1590/0103-6440202004551. 
Feng, H. S., Pinheiro, I. C., Grande, S. R., Pannuti, C. M., Barros, F. J., \& Lotufo, R. F. (2007). Effectiveness of a triclosan/copolymer dentifrice on dental plaque and gingivitis in Brazilian individuals with cerebral palsy. Spec Care Dentist. 27(4), 144-8. 10.1111/j.1754-4505.2007.tb00337.x.

Ferreira, A. C. F. M., Mayer, M. P. A., Kawamoto, D., \& Santos, M. T. B. R. (2019). Constipation, antiepileptic drugs, and gingivitis in children and adolescents with cerebral palsy. Int J Paediatr Dent. 29(5), 635-641. 10.1111/ipd.12488. Epub 2019 Mar 18. PMID: 30817037.

Ferreira, A. C. F. M., Eveloff, R. J., Freire, M., \& Santos, M. T. B. R. (2021). The Impact of Oral-Gut Inflammation in Cerebral Palsy. Front Immunol. 12, 619262. 10.3389/fimmu.2021.619262.

Francis, J. R., Hunter, B., \& Addy, M. (1987). A comparison of three delivery methods of chlorhexidine in handicapped children. I. Effects on plaque, gingivitis, and toothstaining. J Periodontol. 58(7), 451-5. 10.1902/jop.1987.58.7.451.

Garcovich, D., Adobes Martin, M. (2020). Measuring the social impact of research in Paediatric Dentistry: An Altmetric study. Int J Paediatr Dent.30(1), 6674. 10.1111/ipd.12575.

GunnMap 2. http://lert.co.nz/map/

Hurd, W.W. (2014). Case reports in the era of evidence-based medicine. Obstet Gynecol. 124, 409-410. 10.1097/AOG.0000000000000405.

Inal, Ö., Serel Arslan, S., Demir, N., Tunca Yilmaz, Ö., \& Karaduman, A. A. (2017). Effect of Functional Chewing Training on tongue thrust and drooling in children with cerebral palsy: a randomised controlled trial. J Oral Rehabil. 44(11), 843-849. 10.1111/joor.12544.

Jayaratne, Y. S., \& Zwahlen, R. A. (2015). The evolution of dental journals from 2003 to 2012: a bibliometric analysis. PLoS One. 10(3), e0119503. 10.1371/journal.pone.0119503.

Klawonn, M. A., Klamar, K., \& Turk, M. A. (2020). Trends in publications about cerebral palsy 1990 to 2020. J Pediatr Rehabil Med. 13(2), 107-117. 10.3233/PRM-200697.

Liu, F., Wu, T. T., Lei, G., Fadlelseed, A. F. A., Xie, N., Wang, D. Y., \& Guo, Q. Y. (2020). Worldwide tendency and perspectives in traumatic dental injuries: A bibliometric analysis over two decades (1999-2018). Dent Traumatol. 36(5), 489-497. 10.1111/edt.12555.

Loo, C. Y., Graham, R. M., \& Hughes, C. V. (2008). The caries experience and behavior of dental patients with autism spectrum disorder. J Am Dent Assoc. 139(11), 1518-24. 10.14219/jada.archive.2008.0078.

Mann, C. J. (2003). Observational research methods. Research design II: cohort, cross sectional, and case-control studies. Emerg Med J. 20(1), 54-60. 10.1136/emj.20.1.54.

Miamoto, C. B., Ramos-Jorge, M. L., Pereira, L. J., Paiva, S. M., Pordeus, I. A., \& Marques, L. S. (2010). Severity of malocclusion in patients with cerebral palsy: determinant factors. Am J Orthod Dentofacial Orthop. 138(4), 394.e1-394.e5. 10.1016/j.ajodo.2010.03.025.

Mitsea, A. G., Karidis, A. G., Donta-Bakoyianni, C., \& Spyropoulos, N. D. (2001). Oral health status in Greek children and teenagers, with disabilities. J Clin Pediatr Dent. 26(1), 111-8. 10.17796/jcpd.26.1.705x15693372k1g7.

Moraes, R. R., Morel, L. L., Correa, M. B., \& Lima, G. D. S. (2020). A Bibliometric Analysis of Articles Published in Brazilian Dental Journal over 30 years. Braz Dent J. 31(1), 10-18. 10.1590/0103-6440202004550.

Nelson, L. P., Getzin, A., Graham, D., Zhou, J., Wagle, E. M., McQuiston, J., McLaughlin, S., Govind, A., Sadof, M., \& Huntington, N. L. (2011). Unmet dental needs and barriers to care for children with significant special health care needs. Pediatr Dent. 33(1), 29-36.

Ortega, A. O., Guimarães, A. S., Ciamponi, A. L., \& Marie, S. K. (2008). Frequency of temporomandibular disorder signs in individuals with cerebral palsy. J Oral Rehabil. 35(3), 191-5. 10.1111/j.1365-2842.2007.01766.x.

Rai, T., Ym, K., Rao, A., P, A. N., Natarajan, S., \& Joseph, R. M. (2018). Evaluation of the effectiveness of a custom-made toothbrush in maintaining oral hygiene and gingival health in cerebral palsy patients. Spec Care Dentist. 38(6), 367-372. 10.1111/scd.12334.

Rodrigues dos Santos, M. T., Masiero, D., Novo, N. F., \& Simionato, M. R. (2003). Oral conditions in children with cerebral palsy. J Dent Child (Chic). 70(1), $40-6$.

Rosenbaum, P., Paneth, N., Leviton, A., Goldstein, M., Bax, M., Damiano, D., Dan, B., \& Jacobsson, B. (2007). A report: the definition and classification of cerebral palsy April 2006. Dev Med Child Neurol Suppl. 109, 8-14.

Rosenbaum, P. L., \& Dan, B. (2019). The continuing evolution of "Cerebral Palsy". Ann Phys Rehabil Med. Oct 24, S1877-0657(19)30152-6. 10.1016/j.rehab.2019.09.008.

Santos, M. T., Ferreira, M. C., Guaré, R. O., Diniz, M. B., Rösing, C. K., Rodrigues, J. A., \& Duarte, D. A. (2016). Gingivitis and salivary osmolality in children with cerebral palsy. Int J Paediatr Dent. 26(6), 463-470. 10.1111/ipd.12220.

Santos, M. T. B. R., Diniz, M. B., Guaré, R. O., Ferreira, M. C. D., Gutierrez, G. M., \& Gorjão, R. (2017). Inflammatory markers in saliva as indicators of gingival inflammation in cerebral palsy children with and without cervical motor control. Int J Paediatr Dent. 27(5), 364-371. 10.1111/ipd.12270.

Serel Arslan, S., Demir, N., \& Karaduman, A. A. (2017). Effect of a new treatment protocol called Functional Chewing Training on chewing function in children with cerebral palsy: a double-blind randomised controlled trial. J Oral Rehabil. 44(1), 43-50. 10.1111/joor.12459.

Scimago Journal \& Country Rank (SJR). Country Ranking. Dentistry (miscellaneous). https://www.scimagojr.com/countryrank.php?category=3501 
Research, Society and Development, v. 10, n. 13, e299101321279, 2021

(CC BY 4.0) | ISSN 2525-3409 | DOI: http://dx.doi.org/10.33448/rsd-v10i13.21279

Shinohara, E. H., Martini, M. Z., de Oliveira Neto, H. G., \& Takahashi, A. (2004). Oral myiasis treated with ivermectin: case report. Braz Dent J. 15(1), 79-81. $10.1590 / \mathrm{s} 0103-64402004000100015$.

Patil, S. S., Sarode, S. C., Sarode, G. S., Gadbail, A. R., Gondivkar, S., Kontham, U. R., \& Alqahtani, K. M. (2020). A bibliometric analysis of the 100 most cited articles on early childhood caries. Int J Paediatr Dent. 30(5), 527-535. 10.1111/ipd.12641.

PubMed. MEDLINE, PubMed, and PMC (PubMed Central): How are they different? https://www.nlm.nih.gov/bsd/difference.html

Valderrama, P., Valderrama, Á., \& Baca, P. (2020). Bibliometric analysis and evaluation of the journal Medicina Oral Patología Oral y Cirugía Bucal (20082018). Med Oral Patol Oral Cir Bucal. 25(2), e180-e187. 10.4317/medoral.23289.

Van Eck, N. J., \& Waltman, L. (2010). Software survey: VOSviewer, a computer program for bibliometric mapping. Scientometrics. 84(2), 523-538. $10.1007 / \mathrm{s} 11192-009-0146-3$

Yao, H., Wan, J. Y., Wang, C. Z., Li, L., Wang, J., Li, Y., Huang, W. H., Zeng, J., Wang, Q., \& Yuan, C. S. (2018). Bibliometric analysis of research on the role of intestinal microbiota in obesity. PeerJ. 6, e5091. 10.7717/peerj.5091.

Yitzhak, M., Sarnat, H., Rakocz, M., Yaish, Y., \& Ashkenazi, M. (2013). The effect of toothbrush design on the ability of nurses to brush the teeth of institutionalized cerebral palsy patients. Spec Care Dentist. 33(1), 20-7. 10.1111/j.1754-4505.2012.00311.x.

Yoshida, R. A., Gorjão, R., Mayer, M. P. A., Corazza, P. F. L., Guaré, R. O., Ferreira, A. C. F. M., \& Santos, M. T. B. R. (2019). Inflammatory markers in the saliva of cerebral palsy individuals with gingivitis after periodontal treatment. Braz Oral Res. 33, e033. 10.1590/1807-3107bor-2019.vol33.0033.

Yogi, H., Alves, L. A. C., Guedes, R., \& Ciamponi, A. L. (2018). Determinant factors of malocclusion in children and adolescents with cerebral palsy. Am J Orthod Dentofacial Orthop. 154(3), 405-411. 10.1016/j.ajodo.2017.11.042. 